Research Article

\title{
The Development Model of Store Atmosphere in Culinary Business to Increase the Purchasing Interest of Society in the Sub-District of Percut Sei Tuan
}

\author{
Nel Arianty ${ }^{1}$, H. Akrim Ashal Lubis ${ }^{2}$ \\ ${ }^{1,2}$ Faculty of Economics and Business University of Muhammadiyah Sumatera Utara
}

\begin{abstract}
Culinary business has a lot of competition which is faced by business actors. So, in the culinary business, it demands every effort to be able to compete and to defend against competitors. The increasingly fierce competition requires the entrepreneurs to think of the right strategy in competence. This becomes a business opportunity and challenge for every business that operates in Indonesia.

This study aims to make the store atmosphere in culinary business able to compete and to increase the purchasing interest of the society, therefore the purpose in the first year is to conduct a field survey to record and to analyze the culinary business so that people know and are interested to visit and to buy the products that are offered. In the second year is to design and to test model, and to make brochure or pocket book about store atmosphere in culinary business.

From the results of study, it shows that the store atmosphere in culinary business in Sub-District of Percut Sei Tuan if it is viewed from the store exterior indicator, it has less good value with an average value of 3.216, general interior also has less good average value with an average value of $\mathbf{2 . 9 8 4}$, while store layout in the business has good value with an average value of 3.578 means that business owners can maintain by improving existing facilities, store displays have less good average value with an average value of 3.328 .

If it is seen from the results, it is expected that culinary business owners in the Sub-District of Percut Sei Tuan should improve the atmosphere of business place for purchasing interest of society to emerge. Besides store atmosphere indicator, the addition of other indicators is the purchasing interest of the society in which the average value that is generated from the questionnaire is still showing less good value with an average value of 3.3, it means that it becomes a problem for culinary business in Sub-District of Percut Sei Tuan.
\end{abstract}

Key Words: Store Atmosphere, Culinary Business, Purchasing Interest of Society.

\section{INTRODUCTION}

The era of globalization is a challenge and business opportunities for entrepreneurs in Indonesia both small and large scale entrepreneurs. In addition, the era of globalization makes the expansion of product markets and emerges increasingly fierce competition. Food and beverage business is one of the small-scale businesses. Currently, food and beverage business is the trend business. According to data from the Association of Food and Beverage Entrepreneurs in Indonesia/Gabungan Pengusaha Makanan dan Minuman Indonesia (GAPMMI), it is recorded that the value of food and beverage sales reaches 700 trillion in 2012, and in 2013 increases to 800 trillion (Industry Update, 2015).

Viewing the situation, the competition on food and beverage business is also getting tighter. Therefore, food and beverage business or which is commonly called the culinary business needs to increase the strength that exists in its business by giving distinctions and characteristics, in order to have its own attraction that raises the purchasing interest of the society.

Every business actor must have a goal to keep his business running, to earn profits, and to go forward. All those can be achieved if the business actor uses a strategy that is able to compete with other business actors so that the purchasing interest of the society emerges. Competition is a form of business which is carried out in order to get a victory or to get a better position without having a physical clash or conflict.

So, to emerge purchasing interest of society on culinary business can be done by creating a good store atmosphere so that people have an interest to buy. Store Atmosphere will provide a pleasant atmosphere of purchasing environment and will provide added value to the product that is being sold. In addition, the store atmosphere also determines the image of the business itself. Because the image of a good business will ensure the survival of its business and can survive from competitors and can form loyal customers.

From the research results of Dessiana (2013) states by looking at the increasingly fierce competition conditions every business needs to improve the strength that exists in its business by raising the difference or uniqueness which is owned by the company compared with competitors in order to be able to attract consumer purchasing interest. In today's competitive business, market has concentrated on all aspects 


\section{Nel Arianty Dan H. Akrim Ashal Lubis / The Development Model of Store Atmosphere in Culinary Business to Increase the Purchasing Interest of Society in the Sub-District of Percut Sei Tuan}

of their products from production to selling, among all other aspects, store atmosphere has been considered important as POP (point of purchase) for customers (Nugraha, 2013).

According to Kotler (1973) the identity of the store can be communicated to the consumer through store decoration or it is widely seen from its atmosphere. Research results from Turley and Ronald (2000) prove that the atmosphere can influence when consumers are indoors and influence them to make purchases.

This research will be conducted in District of Deli Serdang, especially in Sub-District of Percut Sei Tuan, where in it, there are many culinary business from the initial survey which is conducted by researcher about $80 \%$ of the people in this district run culinary business with very simple store concept and design.

Based on the problems that are faced by the culinary business, a better model and relevant is made to support the problems, to provide solutions, contributions, and to create excellence in an increasingly competitive competition so as to increase the purchasing interest of the society in sub-district of Percut Sei Tuan.

\section{LITERATURE REVIEW}

\subsection{Store Atmosphere}

Levy and Weitz in (Utami, 2010) who points out the 'influence of the store's state is from the character of the store's state, such as architecture, layout, marker, display, color, lighting, temperature, music and aroma, which will thoroughly create an image in the minds of consumers.

While Mowen (2002) says store atmosphere is one component of image in which there is a combination of products on sale, service, customers as a place to enjoy the pleasures of life.

In addition, the store atmosphere is also a combination of several designs that aim to stimulate purchasing interest of society on a product which is offered.

\subsection{Strategy of Store Atmosphere}

Store atmosphere is a strategy that involves various store attributes to attract purchasing interest of consumer. Thus the strategy which is undertaken for store atmosphere is the setting on thew aspects of the instore and outstore atmosphere at the store so that it can influence purchasing interest of consumer on products which are offered by the store.

According to Barry and Evans (2004), Store atmosphere consists of:

\section{Exterior (Outside part of the shop)}

The outside part characteristics of the store have a strong influence on purchasing interest of consumer, so it should be planned as well as possible. The combination of the outside part of the store can make it look unique, attractive, prominent and can invite people to enter the store. The outer elements of this store consist of the following sub elements: a. Storefront (Front part of the shop)

The front of the store includes a combination of nameplate, entrance, and construction of building. The front of the store must reflect the uniqueness, steadiness, sturdiness or other things that fit the image of the store.

b. Marquee (Symbol)

Marquee is a sign that is used to display the name or logo of a store which is combined with slogans and other information.

c. Entrance

The entrance should be designed as well as possible, so it can invite consumers to go into the store and also to reduce in and out at traffic congestion of consumers.

d. Display Window (Window View)

The display window serves to identify a store by displaying goods that reflect the uniqueness of the store so as to attract consumers in.

e. Height and Size Building

May influence a certain impression on the store. For example, the height of the store ceiling can make the room seem more spacious.

f. Uniqueness

The uniqueness of a store can be generated from the design of a store which is distinctive from others.

g. Surrounding Area

The state of the society environment in where a store is located, can influence the image of the store.

h. Parking (Parking Lot)

TempParking lot is important for consumers. If the parking lot is spacious, safe, and has a proximity to the store, it will create a positive Atmosphere for the store.

\section{General Interior (Inside part of the shop)}

The main thing that can make a sale after the buyer is in the store is the display. The interior design of a store should be designed to maximize visual merchandising.

There are many things that will influence consumer perception on the store. According to Barry and Evans (2004), general interior elements consist of:

a. Flooring

The determination of floor type, size, design and color of the floor is very important, because consumers can develop their perception based on what they see.

b. Color and Lighting

Each store must have sufficient lighting to direct or to attract the attention of consumers to a particular area of the store.

c. Scent and Sound

Not all stores provide this service, but if the service is done it will provide a more relaxed atmosphere to the consumer.

d. Fixture (Placement)

Choosing support equipment and table placement should be done well in order to obtain the desired results.

e. Wall Texture 
The texture of the walls can create a certain impression on consumers and can make the wall look more attractive.

f. Temperature

Store managers must set the air temperature, so that indoor air should not be too hot or cold.

g. Width of Aisles

The distance between the table and the chair should be arranged in such a way that consumers feel comfortable and feel at home in the store.

h. Dead Area

Dead Area is a space in the store where normal display can not be applied because it will feel awkward. Eg: entrance, toilet, and corner of the room.

i. Personel (Waitress)

A courteous, friendly, good looking, quick, and responsive waitress will create a company image and customer loyalty.

j. Service Level

Various levels of service according to Kotler which are translated by Teguh, Rusli, and Molan (2000) is self service, self selection, limited service, and full service

k. Price

The price can be listed on the menu which is given so that consumers can know the price of the food.

1. Cash Register

The store manager places the location of the cashier that is easy to reach by the consumer.

m. Technology Modernization

Store managers should be able to serve consumers as sophisticated as possible.

n. Cleanliness

Cleanliness can be a major consideration for consumers to eat at the venue.

3. Room Layout (Store Layout)

Things to consider in designing layouts are as follows:

a. Allocation of floor space for selling, personnel, and customers.

In a store, an existing room should be allocated to:

- $\quad$ Selling Space (Selling Room)

Room to place and the place to interact between consumers and waitresses.

- $\quad$ Personnel Space (Employee Room)

The room which is provided is to meet the needs of the waitress like a place to rest or eat.

- Customers Space (Customers Room)

The room which is provided to enhance the convenience of consumers such as toilets, waiting rooms.

\section{b. Traffic Flow}

Various kinds in determination of store traffic flow, namely:

- Grid Layout (Straight Pattern)

Fixture placement in one long main hallway.

- Loop/Racetrack Layout (Twist Pattern)
It consists of a main hallway that starts from the entrance, circles the entire room, and is usually circular or square, then back to the entrance.

- $\quad$ Spine Layout (Opposite Direction Pattern)

On a spine layout, the main alley extends from front to back of the store, bringing visitors in two directions.

- $\quad$ Free-flow Layout (Free Flow Pattern)

The simplest pattern in which fixtures and items are placed freely.

4. Interior Point of Interest Display (Attractive Decorating In The Store)

Interior point of interest display consists :

a. Theme Setting Display (Theme Decorations)

In a certain season, retailers can design store decorations or ask waitresses to dress according to a particular theme.

b. Wall Decoration (Room Decorations)

Room decoration on the walls can be a combination of drawings or posters that are pasted, the color of the walls, and so on that can improve the atmosphere of the store.

\subsection{The Understanding of Purchasing Interest}

Keller in Dwiyanti (2008) expresses interest in purchasing is how likely consumers are attached to the purchasing interest. While Kotler (2005) states interest is an effective response or process of feeling or liking a product but have not made a decision to purchase.

One way to develop purchasing interest is through promotion which is communication that informs potential buyers about income or obtains a response. According to Swasta in Kristianto (2009) consumer purchasing interests are social actions and relationships that are conducted by individual consumers, groups or organizations to assess, to obtain and to use goods through an exchange or purchase process that begins with a decision-making process that determines those actions.

\subsection{The Factors that Influence Purchasing Interest}

According to Bearman (2007) the growing in purchasing interest of consumer is caused by the elements that consists of:

1. Stimulation

Stimulation is a gesture that is intended to encourage or to cause a person to act.

2. Awareness

Awareness is something that enters a person's mind. Awareness is influenced by consideration of the goods or services themselves.

3. Searching for information

The aspect of searching for information consists of:

a. Internal information is sourced from the consumer's personal in choosing goods or services that can satisfy the needs and desires. 


\section{Nel Arianty Dan H. Akrim Ashal Lubis / The Development Model of Store Atmosphere in Culinary Business to Increase the Purchasing Interest of Society in the Sub-District of Percut Sei Tuan}

b. External information is information that is obtained from outside of the consumer himself such as advertising (print media and direct seller) and social sources (family, friends, colleagues).

c. Ensure the distinctive nature of each option. At this step, consumers collect information which is related to the characteristics and each choice. After determining the choice then the consumer decides which items will be bought.

d. Alternative selection. At this step, it is done if the goods or services are a difficult choice for consumers to evaluate the available alternatives.

e. Purchase. At this step, consumer has made his choice and actually acts to buy goods or services by issuing a sum of money in exchange for the goods or services he obtains.

f. Where to buy. Place of purchase is one of consumer consideration when he is going to buy goods or services.

\subsection{The Relation of Store Atmosphere with Purchasing Interest}

Store atmosphere is a strategy by involving various attributes store to attract consumer purchasing interest. This opinion is supported by the opinion that says store atmosphere can influence a buyer's positive emotional state and the circumstances can cause purchases to occur. A positive emotional state will make the two dominant feelings of pleasure and arousal (Sutisna and Pawitra: 2001). Cooper (1981) who says Store atmosphere that has a beauty will form a positive image in the minds of consumers to the store, and if it lasts long then the tendency of consumers to choose the store is very high. Consumers often judge a store in its first impression from the store's atmosfere, it could be from layout, lighting, music, store colors, and room (Schlosser, 1998). And this is often also the reason why a consumer has an interest or not to shop at the store. A store that has a good "personality" (in this case atmosphere) will have a higher probability of being chosen by a consumer than a bad one. This is in accordance with the theory of consumer behavior that explains about the relation between the aspects of affective and behavior in humans (Kotler 2005). In the theory it is said that behavior arises as a result of affective (feeling) which is owned by consumers. Referring to the theory then if the consumer has a good affective of the product or service, there is the possibility of consumers to make purchases of these products

\section{RESEARCH METHODS}

\subsection{Research Design and Procedure}

This research uses Research and Development (R \& D) method. In line with the objectives to be achieved in this research, it is the development model of store atmosphere in culinary business to increase purchasing interest in the subdistrict of Percut Sei Tuan.

The data collection that will be done is by:
1. In the first year, that is done is identification of store atmosphere problem in culinary business to increase purchasing interest of society.

2. In the second year, to test the model that aims to see how far the benefits of evaluation materials module for the preparation of modules on the development of store atmosphere model in the culinary business and to make the final revision on the development of the ideal store atmosphere model and can increase the purchasing interest of the society.

\subsection{Operational Definition}

1. Variables of store atmosphere consist of:

a. Exterior concerning: (1) The signboard has an attractive design; (2) The entrance of the store is convenient to enter and exit; (3) Store design attracts the attention of consumers; (4) The security of the vehicle when it is parked is well maintained, and (5) The location of culinary business is strategic

b. General interior concerning: (1) The area of culinary business is wide and comfortable; (2) The serving of food menu is interesting; (3) The employees of the culinary business have knowledge about cooking and serve well; (4) Equipment in the culinary business looks traditional and attractive; and (5) Culinary facilities (sink and toilet) look clean

c. Store layout concerning: (1) Available seats are comfortably occupied; (2) The distance between tables makes it easier for consumers to pass by; (3) Food arrangement looks neat and attractive; (4) Placement of proper interior dining facilities; and (5) Placement of payment tables makes transactions easy

d. Interior displays involving: (1) Images and posters look interesting and match the theme; (2) The poster design is always up to date with the latest trends; (3) The guidance sign of the cashier and toilet is clearly visible; (4) Food menu list is clear; and (5) Has a parking lot that is near to the restaurant

2. Variables of purchasing interest consist of:

a. People are interested in purchasing food in this culinary business because of good food and beverage

b. People are interested in buying food in this culinary business because the atmosphere in this place that supports and makes people comfortable to relax

c. People are interested in buying food in this culinary business because of good food and beverage

d. People purchase food here because of fast service

e. People are interested in buying food in this culinary business because the price is relatively cheap if it is compared to other restaurants

\subsection{Data Analysis Technique}

Data analysis techniques use descriptive statistics and analyze store atmosphere to increase purchasing interest.

\section{RESULTS AND DISCUSSION}

4.1. Data Description 
This study is conducted in Sub-district of Percut Sei Tuan, which consists of 20 Sub-districts and to support the data in this study is taken from 5 Sub-districts which is based from initial survey of study which have more culinary business from other sub-districts. From 5 sub-districts, it is taken as sample which is 10 culinary businesses.

\subsection{Data Quality Testing}

Before the data of the questionnaire is further processed, firstly it is tested the validity and reliability of the research measuring instrument to prove whether the measuring instrument that is used has validity and reliability. Based on the results of processing using product moment correlation (index validity) and Cronbach's Alpha method it is obtained the results of validity and reliability test in the following table:

Table 1: Test Results Validity and Reliability Questionnaire Research Variables

\begin{tabular}{|c|c|c|c|c|c|c|c|c|}
\hline $\begin{array}{l}\text { Question } \\
\text { Number }\end{array}$ & $\begin{array}{l}\text { Validity } \\
\text { Index }\end{array}$ & $\begin{array}{l}\text { Reliability } \\
\text { Coefficient }\end{array}$ & $\begin{array}{l}\text { Question } \\
\text { Number }\end{array}$ & $\begin{array}{l}\text { Validity } \\
\text { Index }\end{array}$ & $\begin{array}{l}\text { Reliability } \\
\text { Coefficient }\end{array}$ & $\begin{array}{l}\text { Question } \\
\text { Number }\end{array}$ & $\begin{array}{c}\text { Validity } \\
\text { Index }\end{array}$ & $\begin{array}{l}\text { Reliability } \\
\text { Coefficient }\end{array}$ \\
\hline 1 & 0,617 & \multirow[t]{6}{*}{0,727} & 11 & 0,632 & \multirow[t]{6}{*}{0,704} & 21 & 0,151 & 0,783 \\
\hline 2 & 0,754 & & 12 & 0,665 & & 22 & 0,641 & \\
\hline 3 & 0,696 & & 13 & 0,721 & & 23 & 0,296 & \\
\hline 4 & 0,794 & & 14 & 0,704 & & 24 & 0,655 & \\
\hline 5 & 0,616 & & 15 & 0,687 & & 25 & 0,800 & \\
\hline 6 & 0,683 & & 16 & 0,710 & & 26 & 0,613 & \\
\hline 7 & 0,485 & \multirow{4}{*}{0,736} & 17 & 0,780 & \multirow{4}{*}{0,668} & 27 & 0,635 & \\
\hline 8 & 0,691 & & 18 & 0,579 & & 28 & 0,805 & \\
\hline 9 & 0,552 & & 19 & 0,542 & & 29 & 0,725 & \\
\hline 10 & 0,608 & & 20 & 0,660 & & 30 & 0,472 & \\
\hline
\end{tabular}

In the table above, it shows that the value of the correlation coefficient (index validity) of each item statement is greater than the critical value 0.30 . The results of this testing indicate that all items of statement for each variable is valid and feasible to be used as a research measurement instrument and can be used for further analysis. In the table above, it is also seen that the reliability value on the questionnaire of four variables is greater than the critical value 0.70 . The results of this testing indicate that all the items of statement which are used are reliable so it can be concluded that the questionnaire which is used has given consistent results

\subsection{Descriptive Analysis}

According to Umar (2003) to know the respondents' scores whether it is or not the average scores are divided into four classifications from scale 1 (the lowest) to scale 5 (the highest) that can be calculated by the formula:

$\mathrm{m}(\mathrm{n}-1)$

$$
\text { Average score }=\frac{}{\mathrm{mx} \mathrm{n}}
$$

Note:

$\mathrm{m}=$ total of respondents

$\mathrm{n}=$ total of scales
To find out the respondents' ratings whether it is or not it is used the average score which is divided into four classifications of scale 1 (Strongly disagree), 2 (Disagree), 3 (Less Agree), 4 (Agree) and 5 (Strongly Agree), then it can be calculated by the formula:

Thus, the assessment classification of the overall research variables will be seen from the average score with the following criteria:

$1.00-1.80=$ very bad/very low

$1.81-2.60=\mathrm{bad} / \mathrm{low}$

$2.61-3.40=$ less good

$3.41-4.20=\operatorname{good} /$ high

$4.21-5.00=$ very good/very high

\subsection{Analysis of Research Variables}

The Research Variables are Divided into 4 Variables That Is Exterior (X1) General Interior (X2), Store Layout (X3), Interior Display (X4) And Purchasing Interest (Y), The descriptions Of Each Statement Will Show Response Options of Every Respondent on Each Item Statements that The Author Gives to the Respondents. with the following criteria: Strongly Agree (SA), Agree (A), Less Agree (LA), Disagree (DA), Strongly Disagree (SDA). 
Nel Arianty Dan H. Akrim Ashal Lubis / The Development Model of Store Atmosphere in Culinary Business to Increase the Purchasing Interest of Society in the Sub-District of Percut Sei Tuan

Tabel 2. Exterior Variabel

\begin{tabular}{|c|c|c|c|c|c|c|c|c|c|c|c|c|}
\hline \multirow[t]{2}{*}{ Statement } & \multicolumn{2}{|c|}{ SA } & \multicolumn{2}{|c|}{$\mathbf{A}$} & \multicolumn{2}{|c|}{ LA } & \multicolumn{2}{|c|}{ DA } & \multicolumn{2}{|c|}{ SDA } & \multirow{2}{*}{$\begin{array}{l}\text { Mean } \\
\text { Score }\end{array}$} & \multirow[t]{2}{*}{ Note } \\
\hline & $\sum$ & $\%$ & $\sum$ & $\%$ & $\sum$ & $\%$ & $\sum$ & $\%$ & $\sum$ & $\%$ & & \\
\hline $\begin{array}{l}\text { The signboard has an interesting } \\
\text { design }\end{array}$ & 6 & 6 & 30 & 30 & 62 & 62 & 2 & 2 & 1 & 1 & 3,41 & Good \\
\hline $\begin{array}{l}\text { The entrance of the store is } \\
\text { convenient to enter and exit }\end{array}$ & 7 & 7 & 40 & 40 & 36 & 36 & 15 & 15 & 2 & 2 & 3,44 & Good \\
\hline $\begin{array}{l}\text { Store design attracts the public's } \\
\text { attention }\end{array}$ & 2 & 2 & 2 & 2 & 71 & 71 & 20 & 20 & 5 & 5 & 2,76 & $\begin{array}{l}\text { Less } \\
\text { Good }\end{array}$ \\
\hline $\begin{array}{l}\text { Security of the vehicle when it is } \\
\text { parked is well maintained }\end{array}$ & 5 & 5 & 16 & 16 & 50 & 50 & 26 & 26 & 3 & 3 & 2,94 & $\begin{array}{l}\text { Less } \\
\text { Good }\end{array}$ \\
\hline $\begin{array}{c}\text { The location of culinary business } \\
\text { is strategic }\end{array}$ & 2 & 2 & 56 & 56 & 37 & 37 & 3 & 3 & 2 & 2 & 3,53 & Good \\
\hline
\end{tabular}

From the results of respondent answers it can be seen nameplate which has an interesting design get an average score of 3.41 with a good description because the nameplate that has a good design can influence the purchasing interest of people who feel interested and want to make a purchase. From the statement on the security of the vehicle when it is parked is convenient to enter and exit get an average score of 3.44 which is in good category. The statement on location of the culinary business is strategic is said to be good with an average score of 3.53 . The statement on store design attract public attention has a value of 2.76 that is into less good category. The statement on security of the vehicle when it is parked is less good because the parking is poorly guarded. Based on the above table, it can be concluded that the exterior of the store in the overall view has an average value of 3.216 and is categorized as having less good value, so it is expected that the store's exterior indicators should be more upgraded again

.Tabel 3. General Interior Variable

\begin{tabular}{|c|c|c|c|c|c|c|c|c|c|c|c|c|}
\hline \multirow[t]{2}{*}{ Statement } & \multicolumn{2}{|c|}{$\mathbf{S A}$} & \multicolumn{2}{|c|}{$\mathbf{A}$} & \multicolumn{2}{|c|}{ LA } & \multicolumn{2}{|c|}{ DA } & \multicolumn{2}{|c|}{ SDA } & \multirow{2}{*}{$\begin{array}{l}\text { Mean } \\
\text { Score }\end{array}$} & \multirow[t]{2}{*}{ Note } \\
\hline & $\sum$ & $\%$ & $\sum$ & $\%$ & $\sum$ & $\%$ & $\sum$ & $\%$ & $\sum$ & $\%$ & & \\
\hline $\begin{array}{l}\text { The culinary business area is } \\
\text { spacious and comfortable }\end{array}$ & 1 & 1 & 2 & 2 & 56 & 56 & 39 & 39 & 2 & 2 & 2,57 & Not Good \\
\hline $\begin{array}{l}\text { The serving of the food menu } \\
\text { is interesting }\end{array}$ & 2 & 2 & 7 & 7 & 55 & 55 & 33 & 33 & 3 & 3 & 2,72 & $\begin{array}{l}\text { Less } \\
\text { Good }\end{array}$ \\
\hline $\begin{array}{l}\text { The employees of the culinary } \\
\text { business have knowledge } \\
\text { about cuisine and serve well }\end{array}$ & 1 & 1 & 16 & 16 & 77 & 77 & 3 & 3 & 3 & 3 & 3,09 & $\begin{array}{l}\text { Less } \\
\text { Good }\end{array}$ \\
\hline $\begin{array}{c}\text { The equipment in the culinary } \\
\text { business looks traditional and } \\
\text { interesting }\end{array}$ & 2 & 2 & 2 & 2 & 82 & 82 & 2 & 2 & 1 & 1 & 2,69 & $\begin{array}{l}\text { Less } \\
\text { Good }\end{array}$ \\
\hline $\begin{array}{l}\text { The culinary business } \\
\text { facilities ( sink and toilet) } \\
\text { look clean }\end{array}$ & 15 & 15 & 60 & 60 & 21 & 21 & 3 & 3 & 1 & 1 & 3,85 & Good \\
\hline
\end{tabular}

From the results of respondent responses, it can be seen culinary business facilities (sink and toilet) looks clean get an average score of 3.85 with good category because culinary business facilities (sink and toilet) looks clean can influence the purchasing interest of people who feel interested and want to make a purchase. From the serving of the food menu is interesting with an average score of 2.72 is in less good category. The statement abou the employees of culinary business have knowledge about cuisine and serve well gets an average score of 3.09. Statement about the equipment in the culinary business looks traditional and interesting has a value of 2.69 that fall into the less good category. The statement that the culinary business area is spacious and comfortable can be seen from the average score of 2.57 , it is in not good category. Based on the above table, it can be concluded that the general of the store interior in the overall view has general average value of 2.984 and is categorized to have less good value, so it is expected that the general of the store interior indicators should be further improved. 
Nel Arianty Dan H. Akrim Ashal Lubis / The Development Model of Store Atmosphere in Culinary Business to Increase the Purchasing Interest of Society in the Sub-District of Percut Sei Tuan

Tabel 4. Store Layout Variable

\begin{tabular}{|c|c|c|c|c|c|c|c|c|c|c|c|c|}
\hline \multirow[t]{2}{*}{ Statement } & \multicolumn{2}{|l|}{$\mathbf{S A}$} & \multicolumn{2}{|l|}{$\mathbf{A}$} & \multicolumn{2}{|c|}{ LA } & \multicolumn{2}{|c|}{ DA } & \multicolumn{2}{|c|}{ SDA } & \multirow{2}{*}{$\begin{array}{l}\text { Mean } \\
\text { Score }\end{array}$} & \multirow[t]{2}{*}{ Note } \\
\hline & $\sum$ & $\%$ & $\sum$ & $\%$ & $\sum$ & $\%$ & $\sum$ & $\%$ & $\sum$ & $\%$ & & \\
\hline $\begin{array}{l}\text { Available seats are } \\
\text { comfortable to occupy }\end{array}$ & 20 & 20 & 43 & 43 & 24 & 24 & 12 & 12 & 1 & 1 & 3,69 & Good \\
\hline $\begin{array}{l}\text { Distance between tables } \\
\text { allows consumers to pass } \\
\text { by }\end{array}$ & 29 & 29 & 60 & 60 & 4 & 4 & 5 & 5 & 2 & 2 & 4,09 & Good \\
\hline $\begin{array}{l}\text { Food arrangement looks } \\
\text { neat and attractive }\end{array}$ & 15 & 15 & 45 & 45 & 18 & 18 & 20 & 20 & 2 & 2 & 3,51 & Good \\
\hline $\begin{array}{l}\text { The right placement of the } \\
\text { restaurant interior facilities }\end{array}$ & 16 & 16 & 32 & 32 & 30 & 30 & 10 & 10 & 12 & 12 & 3,30 & Less Good \\
\hline $\begin{array}{l}\text { The placement of the } \\
\text { payment table makes it } \\
\text { easy for transactions }\end{array}$ & 22 & 22 & 20 & 20 & 30 & 30 & 25 & 25 & 3 & 3 & 3,33 & Less Good \\
\hline
\end{tabular}

From the results of respondent responses, it can be seen Available seats are comfortable to occupy get an average score of 3.69 with good category because the seats which are provided by stores are made from comfortable material, it can influence the purchasing interest of people who feel interested and want to make a purchase. From the statement Distance between tables allows consumers to pass by gets an average score of 4.09 with good category. The statement of Food arrangement looks neat and attractive is in good category with an average score of 3.51. The statement of the right placement of the restaurant interior facilities has a value of 3.30 that fall into less good category. The statement of the placement of the payment table makes it easy for transactions is less good category. Based on the above table, it can be concluded that store layout at the shop in the overall view has an average value of 3.578 and has a good value category.

Table 5. Interior Display Variable

\begin{tabular}{|c|c|c|c|c|c|c|c|c|c|c|c|c|}
\hline \multirow[t]{2}{*}{ Statement } & \multicolumn{2}{|l|}{ SA } & \multicolumn{2}{|l|}{$\mathbf{A}$} & \multicolumn{2}{|c|}{ LA } & \multicolumn{2}{|c|}{ DA } & \multicolumn{2}{|c|}{ SDA } & \multirow{2}{*}{$\begin{array}{l}\text { Mean } \\
\text { Score }\end{array}$} & \multirow[t]{2}{*}{ Note } \\
\hline & $\sum$ & $\%$ & $\sum$ & $\%$ & $\sum$ & $\%$ & $\sum$ & $\%$ & $\sum$ & $\%$ & & \\
\hline $\begin{array}{l}\text { Pictures and posters } \\
\text { look interesting and } \\
\text { match the theme }\end{array}$ & 20 & 20 & 32 & 32 & 22 & 22 & 12 & 12 & 8 & 8 & 3,02 & $\begin{array}{l}\text { Less } \\
\text { Good }\end{array}$ \\
\hline $\begin{array}{l}\text { The poster design is } \\
\text { always up to date with } \\
\text { the latest trends }\end{array}$ & 10 & 10 & 20 & 20 & 39 & 39 & 22 & 22 & 9 & 9 & 3,00 & $\begin{array}{l}\text { Less } \\
\text { Good }\end{array}$ \\
\hline $\begin{array}{l}\text { The guidance sign of } \\
\text { the cashier and toilet is } \\
\text { clearly visible }\end{array}$ & 8 & 8 & 21 & 21 & 59 & 59 & 10 & 10 & 2 & 2 & 3,23 & $\begin{array}{l}\text { Less } \\
\text { Good }\end{array}$ \\
\hline $\begin{array}{l}\text { The food menu list is } \\
\text { clear }\end{array}$ & 11 & 11 & 70 & 70 & 10 & 10 & 6 & 6 & 3 & 3 & 3,80 & Good \\
\hline $\begin{array}{l}\text { It has a parking lot that } \\
\text { is adjacent to } \\
\text { restaurant }\end{array}$ & 10 & 10 & 50 & 50 & 29 & 29 & 8 & 8 & 3 & 3 & 3,59 & Good \\
\hline
\end{tabular}

From the results of respondent responses, it can be seen the food menu list is clear in good category with an average score of 3.80 because the menu list which is provided is easy to read can influence the purchasing interest of people who feel interested and want to make a purchase. From the statement it has a parking lot that is adjacent to restaurant with an average score of 3.59 which is in good category. The statement of pictures and posters look interesting and match the theme get an average score of 3.02. The statement of the poster design is always up to date with the latest trends with a value of 3.00 falls into the less good category. The guidance sign of the cashier and toilet is clearly visible statement is obviously in less good category. Based on the above table, it can be concluded that the shop interior display in the overall view has an average value of 3.328 and has less good category, so it is expected that the shop interior display should be more improved. 
Nel Arianty Dan H. Akrim Ashal Lubis / The Development Model of Store Atmosphere in Culinary Business to Increase the Purchasing Interest of Society in the Sub-District of Percut Sei Tuan

Table 6. Purchasing Interest Variable

\begin{tabular}{|c|c|c|c|c|c|c|c|c|c|c|c|c|}
\hline \multirow[t]{2}{*}{ Statements } & \multicolumn{2}{|l|}{ SA } & \multicolumn{2}{|l|}{$\mathbf{A}$} & \multicolumn{2}{|l|}{ LA } & \multicolumn{2}{|c|}{ DA } & \multicolumn{2}{|c|}{ SDA } & \multirow{2}{*}{$\begin{array}{l}\text { Mean } \\
\text { Score }\end{array}$} & \multirow[t]{2}{*}{ Note } \\
\hline & $\sum$ & $\%$ & $\sum$ & $\%$ & $\sum$ & $\%$ & $\sum$ & $\%$ & $\sum$ & $\%$ & & \\
\hline $\begin{array}{l}\text { People are interested in buying } \\
\text { food in this culinary business } \\
\text { because the price is relatively } \\
\text { cheap if it is compared to other } \\
\text { restaurants }\end{array}$ & 13 & 13 & 44 & 44 & 20 & 20 & 15 & 15 & 8 & 8 & 3,39 & $\begin{array}{l}\text { Less } \\
\text { Good }\end{array}$ \\
\hline $\begin{array}{l}\text { People are interested in buying } \\
\text { food in this culinary } \\
\text { business because the cuisine } \\
\text { is more delicious and } \\
\text { comfortable }\end{array}$ & 15 & 15 & 39 & 39 & 21 & 21 & 17 & 17 & 8 & 8 & 3,36 & $\begin{array}{l}\text { Less } \\
\text { Good }\end{array}$ \\
\hline $\begin{array}{l}\text { People are interested in buying } \\
\text { food in this culinary } \\
\text { business because of word of } \\
\text { mouth promotion }\end{array}$ & 4 & 4 & 48 & 48 & 30 & 30 & 11 & 11 & 7 & 7 & 3,31 & $\begin{array}{l}\text { Less } \\
\text { Good }\end{array}$ \\
\hline $\begin{array}{l}\text { The service which is given by } \\
\text { this culinary business is } \\
\text { satisfactory }\end{array}$ & 2 & 2 & 23 & 23 & 41 & 41 & 24 & 24 & 10 & 10 & 2,83 & $\begin{array}{l}\text { Less } \\
\text { Good }\end{array}$ \\
\hline $\begin{array}{l}\text { People are interested in buying } \\
\text { food in this culinary } \\
\text { business because the } \\
\text { atmosphere in this place } \\
\text { supports and makes } \\
\text { consumers comfortable to } \\
\text { relax }\end{array}$ & 10 & 10 & 44 & 44 & 28 & 28 & 10 & 10 & 8 & 8 & 3,38 & $\begin{array}{l}\text { Less } \\
\text { Good }\end{array}$ \\
\hline $\begin{array}{l}\text { People are interested in buying } \\
\text { food in this culinary } \\
\text { business because the food } \\
\text { and beverage are good }\end{array}$ & 13 & 13 & 48 & 48 & 30 & 30 & 6 & 6 & 3 & 3 & 3,62 & Good \\
\hline $\begin{array}{l}\text { This Culinary business is very } \\
\text { concerned to satisfaction }\end{array}$ & 20 & 20 & 35 & 35 & 20 & 20 & 20 & 20 & 5 & 5 & 2,45 & $\begin{array}{l}\text { Less } \\
\text { Good }\end{array}$ \\
\hline $\begin{array}{l}\text { People are interested in buying } \\
\text { food in this culinary } \\
\text { business because the } \\
\text { atmosphere in this place } \\
\text { supports and makes } \\
\text { consumers comfortable to } \\
\text { relax }\end{array}$ & 18 & 18 & 40 & 40 & 32 & 32 & 8 & 8 & 2 & 2 & 3,64 & Good \\
\hline $\begin{array}{l}\text { People are interested in buying } \\
\text { food in this culinary } \\
\text { business because the food } \\
\text { and beverage are good }\end{array}$ & 14 & 14 & 45 & 45 & 30 & 30 & 10 & 10 & 1 & 1 & 3,61 & Good \\
\hline $\begin{array}{l}\text { People buy food here because of } \\
\text { fast service }\end{array}$ & 14 & 14 & 40 & 40 & 25 & 25 & 15 & 15 & 6 & 6 & 3,41 & Good \\
\hline
\end{tabular}

From the results of respondent response, it can be seen the people are interested in buying food in this culinary business because the food and beverages are good get an average score of 3.62 with good category. From statement of people are interested in buying food in this culinary business because the atmosphere in this place supports and makes consumers comfortable to relax get an average score of 3.64 which is in good category. From statement of the people are interested in buying food in this culinary business because the food and beverage are good get an average score of 3.61. The statement about people buy food here because of fast service has a value of 3.41 that fall into good category. The statement about people are interested in buying food in this culinary business because the price is relatively cheap if it is compared to other restaurants are said to be less good with an average score of 3.39. The statement about people are 


\section{Nel Arianty Dan H. Akrim Ashal Lubis / The Development Model of Store Atmosphere in Culinary Business to Increase the Purchasing Interest of Society in the Sub-District of Percut Sei Tuan}

interested in buying food in this culinary business because the cuisine is more delicious and comfortable is said less good with an average score of 3.36. The statement about People are interested in buying food in this culinary business because of word of mouth promotion is said to be less good with an average score of 3.31. The statement about the service which is given by this culinary business is satisfactory is said to be less good with an average score of 2.83. From the statement that people are interested in buying food in this culinary business because the atmosphere in this place supports and makes consumers comfortable to relax is said to be less good with an average score of 3.38. This statement about this culinary business is very concerned to satisfaction is said to be less good with an average score of 2.45. Based on the above table, it can be concluded that the purchasing interest of society in the overall view has an average value of 3.3 and has a less good category, so it is expected that the purchasing interest to the store should be further improved.

\section{DISCUSSION}

Based on the study results that has been presented in the table above, it can be seen that, exterior of the store on food business which is presented by business owners have an average less good value, which from the calculation of the average value of respondents' responses it is obtained an average value of 3.216 and it can be categorized as having less good value, so it is expected in this indicator or store exterior of food company owner should further improve the view of the room which is better and more comfortable, so that visitors are more comfortable and satisfied with the room and it is expected later that more visitors come.

While the indicator of the general interior can be seen in overall has an average value of less good this can be seen from the results of answers and data processing of respondents, in which it is obtained an average value of 2.984 and from the average value it can be categorized in less good value, so it is expected that the indicators of general interior of the store should be further improved, one way of improvements must equip the general interior facilities more completely such as the location of the sink and toilet is clean and fragrant, so for the future many customers come.

Based on the results of the answers and tabulation of respondents data it can be seen that store layout of the shop has a good average value, it is seen from the data processing that it is obtained the average value of 3.578 and can be categorized has a good average value, so it is expected at the shop owner to maintaining that value and if possible the owner can improve the store layout in order to have a very good value, while one way that is done is to improve the parking facilities which is wider and hopefully there will be a smoking area or for a special smoking room so as not to disturb other consumers.

Based on the results of data presentation and tabulation of respondent answers then, it is obtained on the indicator of the shop interior display in overall can have an average less good value in which the results of calculation and data processing is obtained an average value of 3.328. So it can be concluded that the shop interior display in overall has an average value of 3.328 and categorized has a less good value, so it is expected that the shop interior display should be more improved, such as the display poster, baleho or signpost to be better so it can be read and easily found by visitors.

Based on the results of answers and tabulation of respondents, the purchasing interest of the society in overall has an average less good value, it can be seen from the results of data processing it is obtained average value of 3.3 and can be categorized as having a less good value, it is expected to the shop owner can more increase the indicator of consumer purchasing interest by adding more taste of the resulting product and set a standard selling price so that the society as the consumers want to come and are interested to buy products which are offered by the seller, in addition it needs a good service, fast, friendly and good food serving so it is appealing to consumers or visitors, and it is expected to the customers who come will visit again and become regular customers.

\section{CONCLUSION AND RECOMMENDATION}

\subsection{Conclusion}

1. If it is viewed from the questionnaire results of respondents who have been distributed for store atmosphere on culinary business on variables of exterior, general interior, display, they are at less good value. From that, it is expected that culinary business owners pay more attention to the unfavorable variables by updating the design in accordance with the tastes of the society as the consumers.

2. For store layout, from the assessment results of respondent is good, but for the future business owners always give changes as well as improving facilities, especially parking facilities and special space for smoking consumers.

3. Purchasing interest of people from the questionnaire result of respondents have less good value, therefore it is expected that the culinary business owner will give an interesting impression on their business places for arising the purchasing interest of the community.

\subsection{Suggestion}

1. It takes an understanding to the owners of culinary business to the tastes of the society, especially store atmosphere so as to bring the big purchasing interest of society.

2. It takes an understanding to the owners of culinary business to be able to provide the best decoration to attract the attention of the society as the consumers.

\section{ACKNOWLEDGMENTS}

Acknowledgments to the University of Muhammadiyah Sumatera Utara on Dana Hibah Internal/Internal Grant Funds 
Nel Arianty Dan H. Akrim Ashal Lubis / The Development Model of Store Atmosphere in Culinary Business to Increase the Purchasing Interest of Society in the Sub-District of Percut Sei Tuan

through Institute of Research and Community Service/Lembaga Penelitian dan Pengabdian Kepada Masyarakat (LP2M) based on the APB of University of Muhammadiyah Sumatra Utara in accordance with the Agreement Letter of Appointment in the Implementation of Fundamental Research/Program Surat Perjanjian Penugasan Dalam Rangka Pelaksanan Program Penelitian Fundamental of APB UMSU Fund of Fiscal Year 2016.

\section{REFERENCE}

[1] Bank Mandiri Indonesia (2015). Industry update. Retrieved June 6, 2015, from http://www.bankmandiri. co.id

[2] Barry, Berman dan Evans, Joel, 1997,Marketing, Seventh edition, NewJersey:Prentice Hall. Inc.

[3] Bearman. 2007. Retail Management: A Strategic Approch, Ninth Edition, Pretice hall Englewood, Cliffs.

[4] Bosnjak, Michael, Obermeir, Dirk, and explaining the propensity to bid in online auctions : A comparison of two action - theoritical models, Journal pf Consummer Marketing, 17 (3), 203 - 213.Cooper, W, 1981, Ubiquitous Halo.Psychological Bulletin, 90, 218-224.

[5] Dessyana, C. J. (2013). Store Atmosphere Pengaruhnya Terhadap Keputusan Pembelian Konsumen Di Texas Chicken Multimart II Manado. Jurnal EMBA Vol.1 No.3, 844-852.

[6] Influence of Store Atmosphere on Store Inferences. Journal of Consumer Psychology. Vol. 7, No. 4, pp 345369.

[7] Kotler Philip, dan Kevin Lane Keller, 2008, Manajemen Pemasaran, terjemahan

[8] Kotler, Philip. (2005). Manajemen Pemasaran. Edisi kesebelas. Jilid 1. Jakarta: Indeks

[9] Kotler, Philip. 2005. Manajemen Pemasaran. Edisi Bahasa Indonesia. Edisi Kesebelas. Jilid I. Alih Basasa Benyamin Molan. Jakarta: PT. Intan Sejati Klaten

[10] Kurniawan, D. \& Kunto, Y. S. (2013). Pengaruh promosi dan store atmosphere terhadap impulse buying dengan shoping emotion sebagai variabel intervening studi kasus di Matahari Department Store cabang Supermall Surabaya. Jurnal ManajemenPemasaran Petra, 1(2), 1-8. Surabaya: Universitas Kristen Petra.

[11]Levy, Michael and Barton Weitz. 2001. Retailing Management. InternationalEdition. Edisi 4 New York: McGraw-Hill.

[12] Levy, Michael, \& Weitz, Bortom A, 2001, Retailing Management, Fourth edition, Richard D. Irwin Inc.

[13] Monroe and Krishnan. 2008. Basic Marketing Research. New Jersey: Pearson Education.
[14] Mowen, Jhon C. dan Minor, Michael. 2002.Perilaku Konsumen. Jilid Pertama.Alihbahasa: Lina Salim. Jakarta:Erlngga.

[15]Nugraha, B. A. (2013). Persepsi Terhadap Store Atmosphere Dengan Minat Beli Konsumen Di Hypermarket. Jurnal Online Psikologi Vol. 01 No. 02 , 515-528.

[16] Prof. Dr. Thamrin Abdullah, MM, M.Pd dan Dr. Francis Santri, SE,MM(2012), Manajemen Pemasaran, Jakarta, Penerbit PT. Raja Grafindo Persada

[17] Schiffman dan Kanuk (2007), Perilaku Konsumen Edisi Kedua. Jakarta, PT. Indeks Gramedia

[18] Schlooser, 1998, Applying the Functional Theory of Attitudes to Understanding the

[19] Sutisna dan Pawitra dan Pawitra, 2001, Perilaku Konsumen dan Komunikasi Pemasaran,Bandung: Penerbit PT. RemajaRosdakarya.

[20] Swastha, Basu D.H dan Irawan. (2000) . Manajemen Pemasaran Modern. Yogyakarta : Liberty

[21] Turley, L.W., Milliman, R.E.2000. atmospheric effects on Shopping Behavior: AReview of the ExperimentalEvidence.Journal of businessresearch.Vol. 49 pg. 193-211. 